\title{
Pengembangan Taman Toga Sebagai Bahan Baku Resep Toga Berbasis Biosaince pada Kelompok Pkk Rw 7 Bangkong Kecamatan Gunungpati Kota Semarang
}

\author{
Retno Sri Iswari $^{\circledR}$, R. Susanti, Sigit Saptono, Fitri Arum Sasi, Nafisatul Laila \\ Jurusan Biologi, Fakultas Matematika dan Ilmu Pengetahuan Alam Universitas Negeri Semarang, Indonesia
}

\section{Info Artikel}

Diterima: 1 Maret 2021

Disetujui: 30 Maret 2021

Dipublikasikan: 15 April

2021

Keywords: Bangkong

Semarang, Eetnoscience,

Taman toga

Bangkong Semarang,

Eetnoscience, Taman toga

\begin{abstract}
The spread of the COVID-19 virus that has occurred recently is fast the antiviral drugs are not yet available. The spread has to reduce the virus for mild sufferers, self-isolation is requested and for severe sufferers to be isolated in the hospital. One of the efforts to prevent the transmission of COVID-19 is to increase endurance through the use of family medicinal plants (Toga). The potential of medicinal plants as immunomodulators is widely spread in Bangkong village. Bangkong is one of the sub-districts in Semarang City that is also affected by Covid-19, each resident has enough yard to make Toga park. This service activity aims to: (1) provide skills to PKK RW 7 women in designing Toga gardens by making Toga plant racks to decorate their home gardens which can serve as the basic ingredients for making ethnoscience-based Toga recipes; (2) providing knowledge and skills in cultivating Toga; (3) providing knowledge and skills in making ethnoscience-based herbal recipes; (4) providing skills in compiling ethnoscience-based cookbooks about the benefits and ways of presenting them. The approach methods used in the implementation are workshops, lectures/outreach, and training / mentoring. The workshop, given to convey theoretical knowledge about landscape architecture based on land area. In this activity the community service team explained how to make Toga's garden suitable for the land, looking beautiful and free from being damaged by chickens. The results of the training were agreed by the PKK mothers to make Toga in the form of a shelf. It is hoped that the training at the first meeting will produce Toga garden designs that can ensure that each Toga plant can live freely without being disturbed by one another. The lecture method is carried out to explain the benefits of medicinal plants, types of medicinal plants, how to reproduce, and how to treat them. The training method is carried out to provide skills to mothers in making recipes and herbal medicine that can be used to prevent Covid-19 infection. Mothers are very responsive in participating in extension activities on various kinds of plants that can increase endur. After participating in this activity, mothers have understood well the benefits of Toga to increase endurance and prevent being infected with the Corona - 19 viruses.
\end{abstract}

\begin{abstract}
Abstrak
Penyebaran virus covid-19 yang terjadi akhir-akhir ini sangat cepat, obat antivirus belum tersedia. Untuk mengurangi penyebaran virus bagi penderita ringan diminta isolasi diri dan bagi penderita berat diisolasi di rumah sakit. Salah satu upaya pencegahan penularan covid-19 adalah dengan meningkatkan daya tahan tubuh melalui pemanfaatan tanaman obat keluarga (Toga). Potensi tanaman obat sebagai imunomodulator sangat banyak tersebar di lingkungan desa Bangkong. Bangkong merupakan salah satu kelurahan di Kota Semarang juga terdampak covid-19, tiap warga mampunyai halaman yang cukup untk membuat taman Toga. Kegiatan pengabdian ini bertujuan untuk: (1) memberikan keterampilan kepada ibu-ibu PKK RW 7 mendesain taman Toga dengan membuat rak tanaman Toga sebagai penghias halaman rumah yang dapat berfungsi sebagai bahan dasar membuat resep Toga berbasis etnoscience; (2) memberikan pengetahuan dan keterampilan dalam membudidayakan Toga; (3) memberikan pengetahuan dan keterampilan dalam membuat membuat resep jamu berbasis etnoscience; (4) memberikan keterampilan menyusun buku resep berbasis etnoscience tentang manfaat dan cara penyajiannya. Metode pendekatan yang digunakan dalam pelaksanaan adalah workshop, ceramah/penyuluhan, dan pelatihan/pembimbingan. Workshop, diberikan untuk menyampaikan pengetahuan teoritis tentang arsitektur lanskap berdasarkan luas lahan. Pada kegiatan ini team pengabdian menjelaskan bagaimana membuat taman Toga yang sesuai dengan lahan, terlihat indah dan terbebas dirusak oleh ayam. Hasil pelatihan disepakati para ibu PKK membuat Toga dalam bentuk Rak. Pelatihan di pertemuan pertama diharapkan dihasilkan disain taman Toga yang dapat menjamin masingmasing tanaman Toga bisa hidup bebas tidak saling terganggu. Metode ceramah dilakukan untuk memberikan penjelasan tentang manfaat tanaman obat, jenis-jenis tanaman obat, cara memperbanyak dan cara perawatannya. Metode pelatihan dilakukan untuk memberikan keterampilan kepada ibu-ibu dalam membuat resep dan jamu yang dapat digunakan mencegah terkena Covid - 19Setelah mengikuti kegiatan ini, ibu-ibu sudah memahami dengan baik manfaat Toga untuk meningkatkan daya tahan tubuh dan mencegah terinfeksi virus Corona -19
\end{abstract}




\section{PENDAHULUAN}

Taman Toga yang ada di RW 07 dusun Bangkong Kecamatan Gunungpati Semarang perlu diberdayakan karena terlihat sangat tidak terawat. Masih banyak lahan yang belum dimanfaatkan secara intensif, pekarangan dibiarkan ditumbuhi tanaman liar. Taman toga yang dirintis sebelumnya, banyak yang mati karena kurang terawat. Tingginya kesadaran masyarakat tentang pentingnya Toga, menunjukkan sangat berpotensi untuk diberdayakan dalam mengelola Taman Toga. Sebagian besar masyarakat di RW 07 masih belum memanfaatkan lahan pekarangan dengan maksimal. Banyaknya lahan yang masih tersedia dan hanya dibiarkan begitu saja hingga ditumbuhi tanaman liar memberikan peluang untuk mengembangkan tanaman Toga di wilayah RW 07 Bangkong. Ditambah kurangnya pemahaman/ pengetahuan tentang cara-cara memanfaatkan pekarangan rumah dengan baik dan benar. Menurut Kostaman (2010), pekarangan jika dimanfaatkan secara konseptual dengan pendekatan ekosistem dan memperhatikan semua kepentingan yang ada di rumah, seperti kepentingan ibu, bapak, anak-anak, bahkan pembantu, dapat meringankan beban keuangan keluarga yang berarti dapat meningkatkan kualitas hidup keluarga.

Seiring kesadaran masyarakat tentang pentingnya TOGA, maka berkembang pula Taman TOGA dalam berbagai bentuk, diantaranya berbentuk rak bersusun dimana tanaman Toga ditanam di dalam pot, hidrophonik yang dibuat dari botol atau pralon. Khususnya di perkotaan yang pada umumnya, masyarakat di daerah ini tidak banyak yang memiliki lahan cukup luas untuk bercocok tanam maka taman Toga yang dikembangkan berbasis ekosistem dan luasnya lahan cocok bisa mengatasi keterbatasan lahan tersebut. Dalam kehidupan sehari-hari banyak warga yang menggunakan obat-obat alami dan banyak mengenal jenis-jenis tumbuhan berkhasiat obat, namun kurang diaplikasikan dan jenis tumbuhan tsb tidak tersedia di sekitar rumah. Kurangnya pengetahuan masyarakat tentang manfaat Toga di masa pandemi covid-19, cara pengelolaan dan perawatan lahan perlu diberikan pendampingan dan pemberdayaan warga mengingat antusiasme warga pada setiap kegiatan nampak menonjol. Sesuai anjuran dari pemerintah untuk mengkonsumsi tanaman obat keluarga, khususnya empon-empon yang diketahui dapat meningkatakan daya tahan tubuh. Selain itu empon-empon juga berpotensi melindungi tubuh dari infeksi virus, serta betkhasiyat untuk mencegah berbagai macam penyakit, seperti penyakit flu, penyakit jantung dan kencing manis. Namun, Saat ini toga belum banyak diaplikasikan dengan baik, bahkan hidupnya tidak terawat dan terkelola dengan baik. Banyak bagian tumbuhan obat bisa digunakan sebagai obat, diantaranya adalah bagian buah, 
batang, daun, dan akar atau umbi. Oleh karena pentingnya tanaman-tanaman obat tersebut maka kita perlu memahami dengan baik tanaman yang dapat dimanfaatkan sebagai TOGA.

Bagian akar dari empon-empon yang sering disebut dengan rimpang merupakan jenis akar yang dapat digunakan sebagai obat, misalnya (1) jahe (Zingiber officinale). Jahe diketahui mengandung bahan aktif gingerol, shogaol, zingeron, yang bermanfaat memperlancar peredaran darah, memperbaiki fungsi pencernaan, membersihkan darah, antioksidan, imunostimulan, mengatasi batuk, antitumor, dan antivirus. Hasil uji in vitro yang telah dilakukan menunjukkan bahwa jahe dapat digunakan sebagai antivirus pada keluarga kucing yang merupakan vektor untuk norovirus pada manusia yang menyebabkan diare dan muntah-muntah. Hasil uji in vivo diperoleh hasil, bahwa jahe meningkatkan imunitas tubuh. Pemanfaatannya dengan cara rimpang segar digeprek kemudian diseduh atau direbus kenudiab disaring dan diminum; (2) Kunyit (Curcuma domestica), mengandung bahan aktif kurkuminoid. Manfaat rimpang kunyit dapat menjaga stamina, diuretik, antioksidan, antiradang, antidiare, antikanker, dan antivirus. Hasil Uji in vitro menunjukkan bahwa rimpang kunyit dapat digunakan sebagai antivirus HIV, Hepatitis, Influenza A, Herpes, Human Papilloma, Virus pernafasan, Norovirus, dan Arbovirus. Hasil uji in vivo menunjukkan bahwa zat bioaktif rimpang yaitu Curcumin dapat meningkatkan jumlah sel darah putih dalam tubuh, sehingga meningkatkan daya tahan tubuh. Cara pemanfaatannya rimpang segar diparut diperas diminum airnya, rimpang digeprek diseduh air panas atau dengan cara direbus kemudian dasaring dan airnya diminum.

Bagian daun dari tanaman Toga yang bisa dimanfaatkan diantaranya adalah: (1) Meniran (Phyllanthus niruri), mengandung bahan aktif filantin, hipofilantin, tanin, saponin, dan flavonoid.Manfaat daun meniran diantaranya untuk mengobati diare, sariawan, pereda demam, radang ginjal, dan hepatitis. Hasil uji in vitro dan in vivo menunjukkan bahwa daun meniran dapat digunakan sebagai antivirus SRV (Virus penyebab penyakit penurunan kekebalan tubuh pada monyet jenis Macaca) dan virus hepatitis. Hasil uji klinik menunjukkan bahwa daun menirandapat berfungsi sebagai Imunostimulan pada penderita penyakit infeksi seperti TBC dan hepatitis. Cara pemanfaatannya daun meniran segar langsung diseduh dengan air panas atau direbus kemudian disaring dan diminum airnya;(2) Pegagan (Centella asiatica), mengandung bahan aktif asiaticoside, asam asiatik,madekasid. Manfaat daun pegagan diantaranya adalah sebagai imunostimulan, mencerdaskan otak, rematik, asam urat, memusatkan konsentrasi, luka bakar, kanker, kulit, keloid, dan antivirus. Hasil uji in vitro dan in vivo menunjukkan daun pegagan dapat digunakan sebagai antivirus hepatitis, herpes, derivat pektin sebagai imunostimulan, triterpenoid dan saponin sebagai imunomodulator. Cara 
pemanfaatan bisa dibuat jus, dibuat sirup, direbus air panas kemudian disaring dan airnya diminum, dibuat serbuk dengan cara daun dikeringkan terlebih dahulu dalam oven dengan suhu $40-50^{\circ} \mathrm{C}$, setelah daun kering diblender kemudian dibuat serbuk. Serbuk kemudian diseduh dengan air panas atau dimasukkan kapsul, atau daun yang sudah kering diseduh dengan air panas seperti kalau minum teh.

Bagian bunga dari tanaman Toga yang bisa dimanfaatkan diantaranya: (1) Bunga Telang (Clitoria ternatea). Kandungan zat bioaktif dari bunga Telang adalah flavonoid (quercetin), tannin, saponin, cyclotydes (miniprotein), kaempferol, dan ß sitosterol. Manfaat bunga Telang diantaranya untuk obat mata, menurunkan tekanan darah, anti asma, dan penghilang rasa sakit, dan anti tumor serta sebagai. Analisis molecular menghasilkanbunga Telang potensial untuk virus SARS COV-2 (covid 19). Hasil uji in vitro dan in vivo bunga Telang berpotensi sebagai imunostimulan kaempferol, ß sitosterol juga potensial sebagai imunostimulan. Cara pemanfaatannya bunga Telang segar dibuat teh; (2) Bunga Echinacea (Echinacea purpurea) mempunyai kandungan zat bioaktif polisakarida, flavonoid, asam kafeat, minyak atsiri, poliasetilen, alkilamida dan miselaneus. Manfaat bunga Echinacea diantaranya untuk meningkatkan imunitas, antinyeri, membantu melegakan saluran pernafasan atas, melancarkan pencernaan, anti peradangan, anti kanker. Hasil uji in vitro menunjukkan bahwa uji in vitro: bunga Echinacea dapat menstimulasi produksi antibodi dan antivirabunga.

Bagian buah dari tanaman Toga yang bisa dimanfaatkan adalah: (1) Mengkudu (Morinda citrifolia). Buah mengkudu mengandung zat bioaktif Morindone dan alizarin (paling bnayak pada daun), scopoletin (paling banyak pada buah). Manfaat buah mengkudu diantaranya untuk penurun hipertensi, peluruh air seni, melancarkan peredaran darah, menurunkan kolesterol, antioksidan, dan sebagai imunostimulan. Hasil analisis molecular buah mengkudu dinyatakan bahwa buah mengkudu sebagai kandidat penghambat SARS CoV2. Hasil uji in vitro dan in vivo menyatakan bahwa buah mengkudu dinyatakan sebagai imunostimulan. Cara pemanfaatan buah mengkudu dapat dibuat jus buah segar, dibuat simplisia direbus atau ekstrak; (2) Kapulaga Lokal (Amomum compactum), kandungan zat bioaktifnya adalah $\alpha$-pinene, ß-pinene, p-cimene, 1,8 cineole and terpineol. Manfaat buah kapulaga diantaranya sebagai imunostimulan, antiseptik, aromaterapi, memperbaiki fungsi ginjal dan saluran pencernaan serta mencegah kanker. Hasil uji in vivo dan in vitro menyatakan bahwa kapulaga berfungsi sebagai imunomodulator untuk adjuvant pada pengobatan asma. Cara pemenfaatannyadengan cara dibuat simplisia/buah direbus (untuk lebih mantab hasilnya bisa dicampur dengan jahe). 
Bangkong merupakan salah satu dusun di kelurahan sekitar kampus Universitas Negeri Semarang yang terdampak pandemi covid-19. Secara administratif, Kecamatan Gunungpati terbagi menjadi 16 Kelurahan dengan luas wilayah 5.399.085 Ha. Jumlah penduduknya mencapai 70.901 jiwa (20.605 KK) yang terhimpun dari 89 RW dan 418 RT. Kondisi geografis Kecamatan Gunungpati dengan ketinggian dari permukaan air laut $259 \mathrm{~m}$ dan sebagian besar berfungsi sebagai lahan konservasi. Kecamatan Gunungpati berbatasan dengan Kecamatan Mijen dan Kabupaten Kendal (sebelah barat), Kecamatan Ngaliyan dan Gajah Mungkur (sebelah utara), Kecamatan Banyumanik dan Kabupaten Semarang (sebelah timur), dan Kabupaten Semarang (sebelah selatan). Jarak dengan kantor Gubernur 15 KM, jarak dengan Kantor Walikota 18 KM, jarak dengan Kabupaten Semarang 7 KM, jarak dengan Kabupaten Kendal 30 KM. Kecamatan Gunungpati merupakan daerah perbukitan, dengan ketinggian 300 meter dari permukaan air laut. Kecamatan Gunungpati merupakan daerah pengembangan Kota Semarang.

Dalam tata pemerintahan di Kelurahan Bangkong, di wilayah RW 07 terbagi menjadi 2 RT. Berdasarkan hasil wawancara dengan Ketua RW 07, jumlah penduduknya ada 130 KK setiap rata-rata memiliki 3 anak. Mata pencaharian penduduk (ibu-ibu) sebagian besar bekerja sebagai cleaning servis, asisten rumah tangga, ada juga yang bekerja di pabrik, petani, pedagang, dan pekerjaan yang tidak memerlukan keahlian khusus. Sementara bapak-bapaknya ada yang bekerja sebagai buruh sektor informal, tukang batu, sopir taksi, satpam dll. Dalam kehidupan sehari-hari masih banyak yang menggunakan obat-obat alami, terutama penduduk asli yang berusia lanjut.Masih banyak warga asli berusia lebih 60 tahun yang memiliki informasi/pengalaman tentang pengobatan tradisional, yang perlu dilestarikan.

Wilayah RW7 sebagian besar merupakan tanah yang subur. Meskipun tanahnya subur, masih banyak lahan yang belum dimanfaatkan secara intensif. Kebun dan pekarangan rumah banyak yang dibiarkan ditumbuhi tanaman liar. Padahal seharusnya kalau pekarangan ini dikelola dengan baik ditanami dengan beranekaragam jenis tanaman, ada yang berumur panjang, berumur pendek, menjalar, memanjat, semak, pohon rendah dan tinggi serta terdapat ternak, dipelihara secara benar dan baik akan memberikan hasil yang tidak ternilai. Sebagaian besar warga asli memiliki lahan kebun/pekarangan yang cukup luas, sementara lahan pekarangan warga pendatang terbatas sekitar 2-5 m2 saja. Beberapa warga masyarakat mengenal jenis-jenis tumbuhan berkhasiat obat, namun kurang diaplikasikan dalam kehidupan sehari-hari serta tidak tersedia di sekitar rumah. Banyak tanaman yang berkasiat obat pada daunnya, buah atau bijinya, umbinya, kulit batang dll.Obat-obatan herbal biasanya tidak merupakan tumbuhan 
tunggal tetapi campuran dari beberapa jenis tanaman, dengan dosis yang berbeda-beda untuk mengobati penyakit yang berbeda pula.Hal ini sangat diperlukan terutama untuk pertolongan dini penyakit, untuk maintenance kesehatan dan pada kondisi darurat seperti pandemi covid-19 saat ini.Meskipun melalui PKK juga dianjurkan mempunyai sedikitnya 5 (lima) jenis tanaman obat keluarga di rumah, namun kenyataannya, belum banyak warga PKK yang melaksanakannya. Taman toga yang dirintis sebelumnya, tanamannya banyak yang mati karena tidak terawat. Kurangnya pengetahuan masyarakat tentang manfaat toga di masa pandemi covid-19, carapengelolaan, perawatan dan pemanfaatan taman toga merupakan permasalahan utama yang dihadapi mitra. Latar belakang pendidikan dan antusiasme pada setiap kegiatan, menunjukkan warga PKK RW 7 sangat berpotensi untuk diberdayakan dalam mengelola "Taman toga".

Kelompok ibu-ibu PKK RW 7 Bangkong merupakan kumpulan ibu-ibu yang sudah lama terbentuk dan tetap eksis sampai sekarang. Aktivitas utama ibu-ibu yang tergabung dalam kelompok ibu-ibu PKK RW 7 ini adalah arisan yang dilaksanakan secara bergilir dari rumah ke rumah. Hal ini merupakan salah satu upaya untuk lebih menjalin silaturahmi dan menjalin keakraban di antara sesama anggota PKK RW 7. Kegiatan ibu-ibu PKK RW 7 tidak hanya terbatas pada kegiatan arisan, setiap pertemuan bulanan juga dirangkaikan dengan berbagai demonstrasi/penyuluhan yang berkaitan dengan aktivitas ibu-ibu seperti masak memasak, busana dan sebagainya. Aktivitas sosial ibu-ibu yang tergabung dalam PKK RW 7 yang menjadi mitra cukup baik. Hal ini dapat dilihat dari adanya kekompakan ibuibu PKK RW 7 apabila ada kegiatan kerja bakti, ibu-ibu turut berpartisipasi dalam mempersiapkan konsumsi. Demikian juga apabila ada anggota keluarga dari warga yang sakit atau berduka, maka ibu-ibu PKK RW 7 akan bersama-sama berkunjung ke rumah warga yang berduka. Demikian juga bila ada acara syukuran pernikahan atau aqiqah, ibu-ibu berpartisipasi membantu warga yang memiliki hajatan tersebut.

Ibu-ibu yang tergabung dalam PKK RW 7 di Kelurahan Sekaran ini rata-rata merupakan ibu-ibu muda yang aktif yang bekerja sebagai cleaning servis, asisten rumah tangga, ada juga yang bekerja di pabrik, petani, pedagang, dan pekerjaan yang tidak memerlukan keahlian khusus. Namun demikian, meskipun memiliki kesibukan yang cukup padat, ibu-ibu anggota PKK RW 7 tetap kompak dan selalu meluangkan waktu untuk mengikuti pertemuan bulanan yang dirangkaikan dengan arisan. Karena saat itulah ibu-ibu berbagi cerita sesama anggotanya, dan terkadang ibu-ibu yang mempunyai bisnis menjadikan momen tersebut untuk memasarkan barang atau bisnisnya. 
Ibu-ibu yang tergabung dalam PKK RW 7 juga mempunyai hobi menanam tanaman, hampir setiap halaman rumah dihiasi dengan tanaman, ada yang ditanam di pot dan ada pula yang ditanam langsung di tanah di depan rumah sepanjang pagar. Jenis tanaman yang banyak ditanam adalah mawar, lidah mertua, kenanga dan cabe yang mempunyai khasiat bagi kesehatan. Hanya beberapa rumah yang didapati menanam empon-empon di halaman rumahnya. Hal ini karena mitra belum memahami dengan baik manfaat dari tanaman emponempon sehingga perhatian mitra lebih banyak tertuju pada tanaman yang menghasilkan bunga dan buah.

Pengetahuan ibu-ibu PKK RW 7 tentang tanaman Toga masih terbatas pada tanaman hias. Pengetahuan mitra tentang manfaat tanaman Toga sebagai imunostimulan dan kemampuannya dalam meningkatkan daya tahan tubuh belum banyak diketahui. Oleh karena itu, tanaman yang banyak menghiasi ruangan baik di ruangan tamu maupun di ruangan. Jenisjenis tanaman Toga yang ditanam oleh mitra juga masih terbatas. Hal ini karena pengetahuan mitra tentang jenisjenis tanaman Toga dan teknik budidaya tanaman Toga masih kurang. Padahal tanaman Toga yang ada di Indonesia ada ratusan jenis. Tanaman Toga selain dapat ditanam dalam pot tanah/porselen, juga dapat ditanam dalam wadah plastic, maupun ember bekas cat sehingga perawatannya lebih mudah karena tidak perlu disiram setiap hari. Dengan demikian maka penanaman dengan teknik ini sangat cocok untuk diterapkan mengingat mitra sebagian besar adalah ibuibu muda yang aktif.

Secara nyata mitra mengalami beberapa permasalahan dalam upaya menjadikan tanaman Toga di lahan pekarangan maupun dalam rumahnya yaitu: (1) Belum mengetahui Toga sebagai obat untuk meningkatkan daya tahan tubuh; (2) Belum mengetahui tentang jenis-jenis tanaman Toga dan teknik budidayanya; (3) Belum memiliki pengetahuan dan keterampilan dalam menanam tanaman Toga.

Melihat permasalahan yang ada maka solusi yang ditawarkan adalah upaya untuk meningkatkan pengetahuan dan keterampilan mitra dalam memanfaatkan tanaman Toga sebagai bahan baku pembuatan resep obat tradisional. Berdasarkan masalah utama yang teridentifikasi dari serangkaian masalah yang dihadapi oleh mitra dalam memanfaatkan taman Toga sebagai bahan baku untuk membuat membuat resep Toga berbasis etnoscience, yaitu dalam peningkatan kemampuan dan teknologi budidaya tanaman Toga berdasarkan ekosstem dan luasnya lahan, maka solusi yang ditawarkan berupa: (1) pendekatan alih teknologi dan peningkatan kemampuan melalui penyuluhan dan pelatihan; (2) penyediaan sarana atau komponen pendukung teknologi budidaya tanaman Toga dengan membuat rak tanaman; (3) 
memperindah dan menyegarkan halaman rumah dengan tanaman Toga; dan (4) membantu pemerintah Kota Semarang dalam usaha memperkenalkan teknologi budidaya tanaman Toga berbasis ekosistem dan luas lahan sehingga tanaman Toga dapat dijadikan tanaman hias dan sekaligus sebagai bahan baku untuk pembuatan buku resep obat berbasis etnoscience.

\section{METODE}

\section{Workshop pembuatan arsitektur lanskap sesuai ketersediaan lahan}

Metode ini diberikan untuk menyampaikan pengetahuan teoritis tentang (1) jenis-jenis tanaman obat dan manfaatnya; (2) budidaya tanaman obat; dan (3) arsitektur lanskap berdasarkan luas lahan. Pada kegiatan ini diikuti oleh semua warga RW7, kecuali untuk arsitektur lanskap dipilih 5 orang untuk masing-masing RT. Peserta diharapkan sudah memiliki data luas lahan yang akan dibuat taman Toga. Setiap dawis 1 taman toga, jadi diharapkan ada 4 taman Toga pada RW tujuh. Waktu pelaksanaan dilakukan di awal kegiatan serta bersamaan dengan kegiatan praktik (bersifat terpadu antara teori dan praktik).

\section{Koleksi dan praktek menanam Toga sesuai lanskap yang telah dibuat}

Koleksi tanaman dilakukan berdasarkan data yang telah dikumpulkan sebelumnya. Tanaman dapat diperoleh dari warga sekitar atau membeli dari penjual bibit Toga. Proses penanaman diatur sesuai lanskap dan jenis tanaman. Semua jenis tanaman diberi identitas nama.

Penanaman dilakukan secara gotong royong untuk setiap warga RT, karena seriap RT membuat 1 contoh "taman Toga". Masing-masing taman Toga diberi nama sesuai kesepakatan warga. Meskipun jenis koleksi tanamannya sama, tetapi arsitektur lanskapnya bisa berbeda-beda sesuai ketersediaan lahan.

\section{Pendampingan cara pengelolaan, perawatan dan pemanfaatan tanaman obat}

Pengelolaan taman toga dilakukan secara terorganisir, dengan mekanisme pembentukan struktur organisasi dan pembagian tugas. Setiap dawis memiliki tanggung jawab mengelola satu taman Toga, sehingga koordinasinya lebih mudah karena jumlah warganya lebih sedikit (sekitar 10-15 KK). Perlu juga dilakukan kerja bersama, setiap periode tertentu (misalnya 3 bulan sekali) sekaligus bisa koordinasi untuk pengembangan ke depannya.

Perawatan taman toga dilakukan secara organik atau sesedikit mungkin menggunakan bahan kimia sehingga hasil yang diperoleh lebih baik. Bahan organik berasal dari sisa tanaman, limbah ternak, limbah rumah tangga. Limbah ini kemudian dirajang (ukurannya diperkecil) untuk memudahkan proses fermentasi/pengomposan. Proses pengomposan dapat dipercepat dengan menggunakan biodekomposer yang banyak dijual di pasaran (EM4, STARDEC, BIODEC, dan lain-lain).

\section{Pendampingan membuat buku resep Toga berbasis etnoscience}

Pembuatan buku resep Toga berbasis etnoscience dilakukan dengan mengumpulkan resep yang pernah digunakan dan dimiliki oleh masing-masing anggota PKK RW 7. Kemudian resep tersebut 
dipraktekkan, dilakukan uji organoleptik, kemudian didata untuk dimasukkan ke dalam buku resep Toga berbasis etnoscience. Kekurangan jumlah resep diperoleh dari resep jadul dr.Zaidul Akbar dan dari internet. Setelah lay out resep Toga berbasis etnoscience selesai dibuat diserahkan ke percetakan untuk dicetak.

\section{HASIL DAN PEMBAHASAN}

\section{Workshop}

Kegiatan workshop adalah kegiatan pelatihan pembuaatan rak bersusun tiga yang sesuai dengan lahan, terlihat indah dan terbebas dirusak oleh ayam yang bertujuan untuk memberikan pengetahuan dan ketermpilan kepada ibu-ibu dalam membuat rak bersusun tiga yang dapat ditempatkan di pelataran rumah. Kegiatan pembuatan rak bersusun 3 dimulai dengan menunjukkan bahan dan alat yang digunakan pada pembuatan rak bersusun 3. Kemudian dipraktekkan oleh team pengabdian tahapantahapan pembuatan rak bersusun 3 mulai dari pemilihan wadah, media, bahan tanaman sampai pada pembuatan nutrisi hidroponik (Gambar 1). Pada pelatihan ini digunakan media siap pakai yaitu nutrisi hidroponik AB mix, pupuk NPK dan Gandasil D dan diajarkan juga cara membuat pupuk cair dari sisa limbah keluarga khususnya dari jenis tumbuhan dan hewan. Pada kegiatan ini team pengabdian menjelaskan bagaimana membuat taman Toga yang sesuai dengan lahan, terlihat indah dan terbebas dirusak oleh ayam.

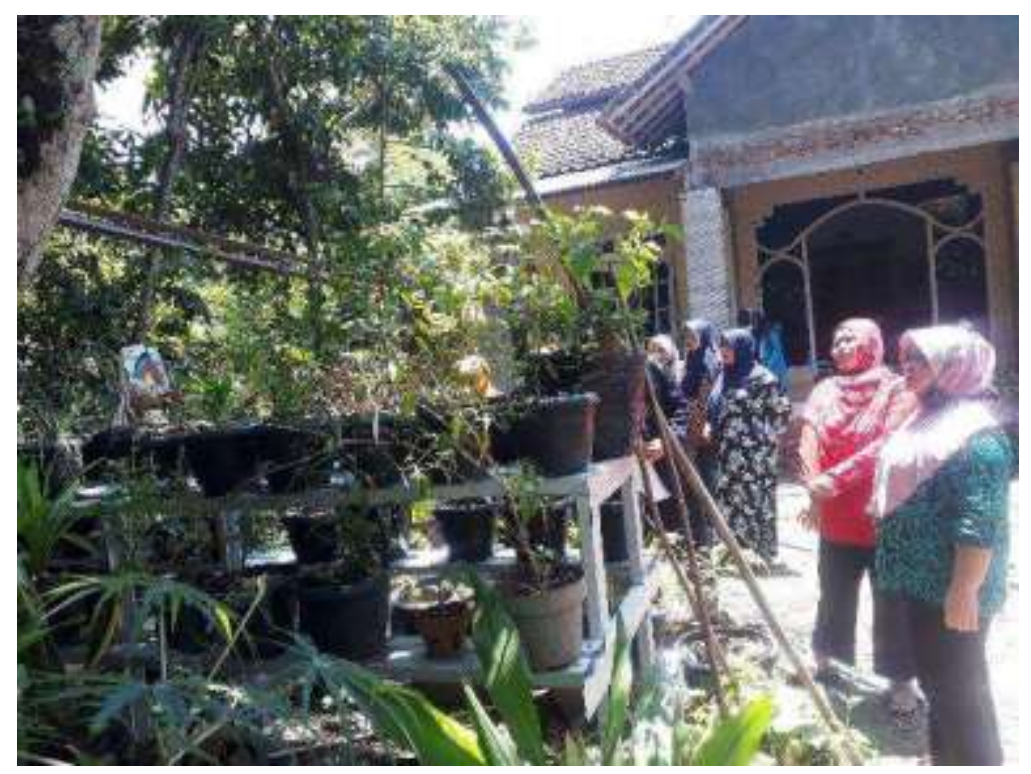

Gambar 1. Rak bersusun 3 yang berhasil dibuat oleh team pengabdian dibantu ibu-ibu PKK RW 7.

Pelatihan dilakukan dengan memberikan kesempatan kepada mitra untuk mempraktekkan sendiri cara membuat rak bersusun 3 sesuai dengan tahapan yang telah diberikan pada kegiatan ceramah dan demonstrasi sambil memberikan bimbingan kepada peserta yang mengalami kesulitan dalam melakukan kegiatan praktek. Kegiatan ini berlangsung dengan sangat baik. Peserta sangat bersemangat mengerjakan 
tahapan-tahapan pembuatan rak bersusun 3 hingga selesai. Suasana praktek pembuatan rak bersusun 3 dapat dilihat pada Gambar 2.

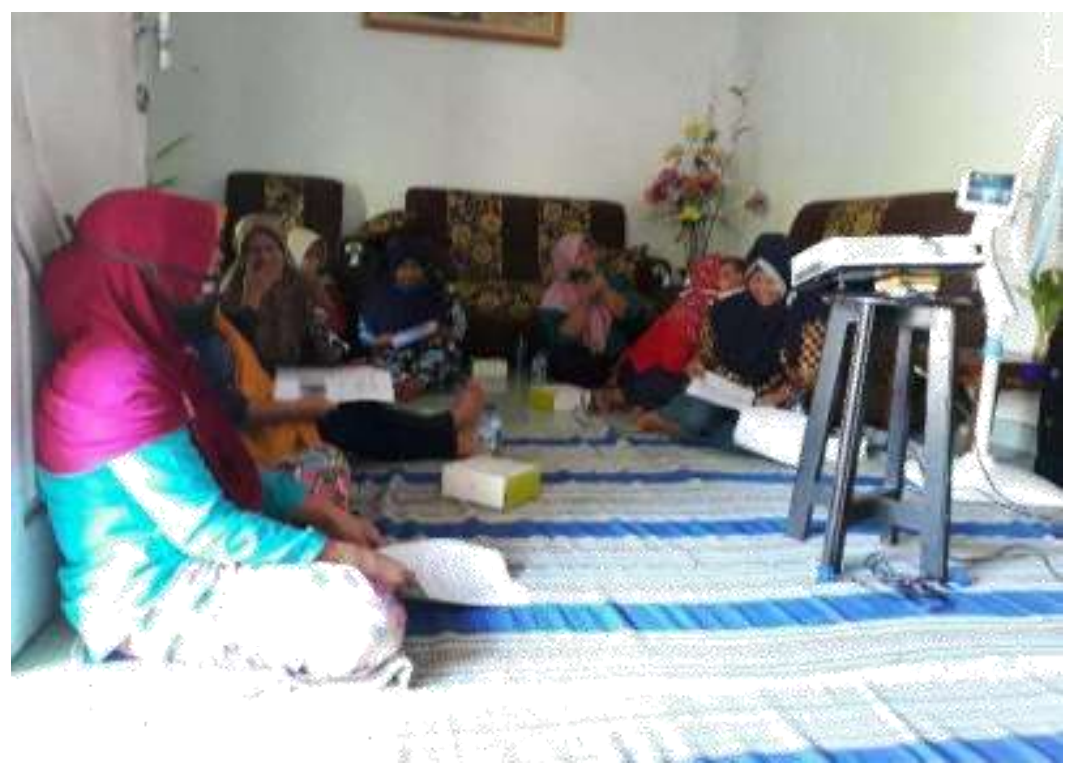

Gambar 2. Suasana workshop pembuatan rak bersusun 3

\section{Penyuluhan}

Berdasarkan hasil kuisioner yang dibagikan kepada peserta sebelum dan sesudah kegiatan ceramah/penyuluhan dimulai, diperoleh hasil bahwa sebagian besar peserta belum mengetahui tentang jenisjenis tanaman Toga. Namun, setelah diperlihatkan jenis-jenis tanaman yang termasuk Toga, peserta baru mengetahui bahwa beberapa jenis tanaman yang peserta tanam di halaman rumah tergolong tanaman Toga. Beberapa jenis tanaman Toga yang diperlihatkan pada saat kegiatan dapat dilihat pada Gambar 3.

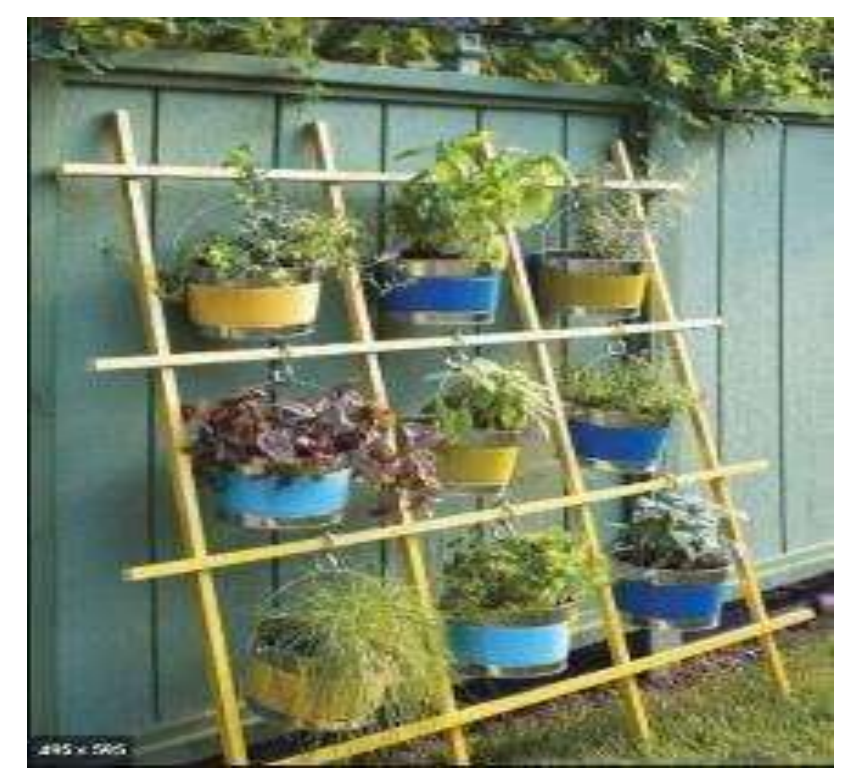

Gambar 3. Beberapa jenis tanaman Toga 
Manfaat tanaman Toga selama ini yang diketahui oleh ibu-ibu peserta hanya sebatas bisa mengobati saja. Namun, setelah mengikuti kegiatan pengabdian ini, peserta mengetahui berbagai kandungan zat bioaktif yang menyebabkan tanaman Toga bisa meningkatkan daya tahan tubuh dan mengobati beberapa macam penyakit. Terutama manfaat tanaman obat sebagai obat penurun kolesterol, dapat mengobati penyakit jantgung, hepatitis dan penyakit ginjal serta bisa digunakan sebagai bahan dasar membuat handsanitizer yang berguna untuk terhindar dari paparan Corona atau Covid 19. Setelah mengikuti kegiatan ini, ibu-ibu bisa memanfaatkan empon-empon sebagai usaha untuk meningkatkan daya tahan tubuh dengan cara diseduh, simplisia atau dibuat jus. Juga bisa menanam tanaman Toga sesuai lahan dan terbebas dari serangan ayam, dengan cara menempatkan tanaman Toga di rak bersusun, sedangkan untuk memperindah halaman rumah ibu-ibu sudah terampil mendesain tanaman Toga yang ditanam di pelataran rumah maupun ditepi-tepi tembok rumah.

\section{Pelatihan}

Kegiatan selanjutnya adalah pelatihan kegiatan menanam toga sesuai dengan lanskap yang telah dibuat, membuat jamu berbasis etnoscience, dan menyusun buku resep Toga berbasis etnoscience. Tujuan pelatihan ini untuk memberikan pengetahuan dan keterampilan kepada ibu-ibu dalam menanam toga sesuai dengan lanskap yang telah dibuat, membuat jamu berbasis etnoscience, dan menyusun buku resep Toga berbasis etnoscience.

Kegiatan pelatihan menanam Toga dimulai dengan menunjukkan bahan dan alat yang akan digunakan untuk menanam Toga seperti pot dan polyback sebagai jenis wadah, tanah siap pakai sebagai media yang sudah dilengkapi dengan nutrisi yang dibutuhkan oleh tanaman Toga. Kemudian dipraktekkan tahapan-tahapan penanaman tanaman Toga mulai dari pemilihan wadah, media, bahan tanaman sampai pada pembuatan pupuk cair dari lembah rumah tangga (Gambar 4).

Kegiatan pelatihan pembuatan jamu berbasis etnoscience, pada kegiatan ini team pengabdian memberikan pendampingan pada pembuatan jamu yang sudah biasa dibuat untuk mengobati anggota keluarga maupun untuk dirinya sendiri. Di akhir pelatihan masing-masing peserta menghasilkan paling sedikit satu resep jamu tradisional berbasis Toga.

Kegiatan menyusun buku resep Toga berbasis etnoscience yang berisi identitas tanaman (nama jawa atau dan ilmiah), gambar tanaman (foto), kegunaan, cara membuat dan manfaatnya., diatihkan pada peserta sampai dihasilkan draf buku "Resep Toga berbasis Etnosciences". Semua informasi tersebut berasal dari data yang dikoleksi dan tanaman yang telah ditanam di "taman Toga". Sebelum disusun menjadi buku, semua data diinformasikan ke semua warga, sebagai bahan diskusi dan koreksi. Bimbingan secara on line melalui WhatsApp. Bila dirasa draf buku sudah siap cetak, selanjutnya draf dimasukkan di percetakan untuk dicetak menjadi buku. 


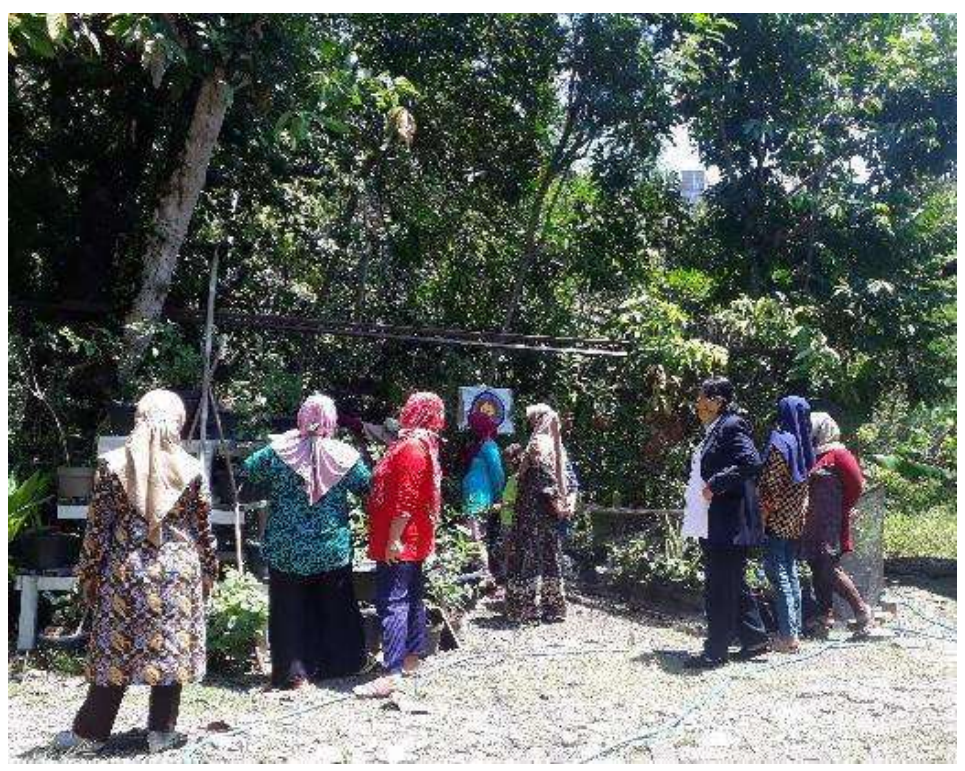

Gambar 4. Peserta dan hasil karyanya

Hasil karya ibu-ibu peserta semuanya sangat menarik dan bervariasi sesuai dengan selera masingmasing peserta. Hasil karya masing-masing peserta dibawa pulang ke rumah untuk ditempatkan di halaman rumah. Ibu-ibu yang telah mengikuti kegiatan penyuluhan dan pelatihan sudah memiliki pengetahuan tentang manfaat manfaat Toga bagi kesehatan tubuh. Peserta juga sudah dapat membuat rak bersusun. Menanam tanaman Toga, cara pengelolaan dan perawatan tanmaan serta membuat jamu dan resep berbahan dasar tanaman dari taman Toga. Ibu-ibu peserta kegiatan juga sudah mulai menempatkan beberapa tanaman Toga dalam pot di dalam rumah dan di luar rumahnya. Ibu-ibu juga sudah merasakan manfaat Toga sebagai obat maupun untuk meningkatkan daya tahan tubuh. Saat ini, ibu-ibu tidak lagi membeli jamu gendong, cukup dengan menyeduh bagian tanaman Toga sesuai dengan kebutuhannya.

\section{SIMPULAN}

Dari kegiatan pengabdian yang telah dilakukan dapat disimpulan bahwa: (1) Ibu-ibu PKK RW 7 mempunyai pengetahuan dan keterampilan dalam mendesain arsitektur lanskap "Taman Toga" yang indah sesuai luas lahan; (2) Ibu-ibu PKK RW 7 mempunyai pengetahuan dan keterampilan dalam mengoleksi dan menanam Toga sesuai lanskap yang dibuat; (3) Ibu-ibu PKK RW 7 terampil dalam mengelola, merawat dan mamanfaatkan jenis-jenis tanaman obat dari "Taman Toga" yang fungsional; (4) Ibu-ibu PKK RW 7 terampil mengolah, mengemas dan mamanfaatkan jenis-jenis tanaman obat dari "Taman Toga” yang menyehatkan, Ibu-ibu PKK RW 7 berhasil menyusun buku resep Toga berbasis etnoscience 


\section{UCAPAN TERIMA KASIH}

Terima kasih kepada Universitas Negeri Semarang yang telah mendanai kegiatan pengabdian ini melaluidana DIPA Universitas Negeri Semarang tahun 2020 dengan nomor: 44.23.4/ UN37/PPK3.1/2020, tanggal 23 April 2019.

\section{DAFTAR PUSTAKA}

Ayameang, O., Rattarom, R., Mekjaruskul, C., Caichompoo, W. (2020). Anti-Inflammatory Activity and Quantitative Analysis of Major Compounds of the Mixtures of Derris scandens (DZSS) Formula.Pharmacognosy Journal, 12(4), 828-834

De Toledo, L.G., Ramos, M.A.D.S., Sposito, L., Castilho, E.M., Pavan, F.R., Lopes, E.D.O., Zocolo, G.J., Silva, F.A.N., Soares, T.H., Santos, A.G.D., Bauab, T.M., and Almeida, M.T.G.D. (2016). Essential oil of Cymbopogon nardus (L.) Rendle: A strategy to combat fungal infections caused by Candida species. International Journal of Molecular Sciences, 17(8), 1252

Gugus tugas percepatan penanganan COVID19 di Indonesia. (2020). Data COVID-19 di Indonesia.www.covid19.go.id. Diakses tanggal 6 September 20

Jantan, I., Saputri, F.C., Qaisar, M.N., Buang, F. (2012). Correlation between Chemical Composition of Curcuma domestica and Curcuma xanthorrhiza and Their Antioxidant Effect on Human LowDensity Lipoprotein Oxidation.Evidence-Based Complementary and Alternative Medicine, 2012, 10 pages.

Keputusan Menteri Kesehatan Republik Indonesia Nomor Hk.01.07/Menkes/413/2020 Tentang Pedoman Pencegahan Dan Pengendalian Coronavirus Disease 2019 (Covid-19).

Kostaman, T. (2010). Pemanfaatan Pekarangan. Materi untuk workshop training P2KP.

Kumar, A. (2020). Phytochemistry, pharmacological activities and uses of traditional medicinal plant Kaempferia galanga L. An overview.Journal of Ethnopharmacology, 253, 112667.

Mirabeau, T.Y. and Samson, E.S. (2012).Effect of Allium cepa and Allium sativum on some immunological cells in rats.African Journal of Traditional, Complementary and Alternative Medicines, 9(3), 374-379.

Prasanna, V.K. and Venkatesh, Y.P. (2015). Characterization of onion lectin (Allium cepa agglutinin) as an immunomodulatory protein inducing Th1-type immune response in vitro.International Immunopharmacology, 26(2), 304-313)

Rahim, E., Ismail, A., Omar, M.N. (2018). GC-MS analysis of phytochemical compounds in Syzygium polyanthum leaves extracted using ultrasound-assisted method. Pharmacognosy Journal, 10 (1), 110119

Sowley, E.N.K. and Kankam, F. (2019). Harnessing the Therapeutic Properties of Ginger (Zingiber officinale Roscoe) for the Management of Plant Diseases.In Ginger Cultivation and Its Antimicrobial and Pharmacological Potentials.Haiping Wang, IntechOpen.

Tip-pyang, S., Sathanasaiwapak, S., Kokpol, U., and Phuwapraisirisan, P. (2000). Antibacterial flavonoids from Bosenbergia pandurata.ACGC Chemical Research Communications, 10, 21-26.

WHO (2020). Coronavirus disease (COVID-19) pandemic. https://www.who.int/ emergencies/diseases/novel-coronavirus-2019.Diakses tanggal 6 September 2020. 